\title{
METHANOLIC FLOWER EXTRACT OF PHLOGACANTHUS THYRSIFLORUS NEES. ATTENUATES DIABETIC NEPHROPATHY IN ALLOXAN-INDUCED DIABETIC MICE
}

\author{
JUTISHNA BORA, DONKUPAR SYIEM, SURYA BHAN*
}

Department of Biochemistry, North Eastern Hill University, Shillong - 793 022, Meghalaya, India. Email: sry_bhan@yahoo.co.in

Received: 20 February 2017, Revised and Accepted: 28 March 2018

\section{ABSTRACT}

Objectives: The aim of the present study is to determine the effects of Phlogacanthus thyrsiflorus on hyperglycemia and oxidative stress in kidneys of diabetic mice.

Methods: Aqueous flower extract (AFE) and methanolic flower extract (MFE) were prepared. Preliminary phytochemical screenings were carried out. Diabetic mice were prepared by administering alloxan at $150 \mathrm{mg} / \mathrm{kg}$ body weight (b.w). The effects of different doses (150-550 mg/kg b.w) of the MFE on hyperglycemia were examined for short-term duration in diabetic mice. Activities of antioxidant enzymes, superoxide dismutase (CuZn-SOD and Mn-SOD), catalase (CAT), and glutathione reductase (GR) were examined under normal, diabetic, and diabetic-treated groups. Histopathological studies were also carried out for the above groups.

Results: It has been found that the flavonoids and tannins were strongly present in MFE and further in vivo studies with MFE were carried out. It has been also observed that $250 \mathrm{mg} / \mathrm{kg}$ b.w dose of MFE showed significant reduction of blood glucose level. The activities of SOD, CAT, and GR increased in diabetic mice treated with MFE. Histological studies showed that MFE could further halt the damage caused by oxidative stress and reduced tissue injuries in diabetic mice.

Conclusion: MFE of $P$. thyrsiflorus has positive effects in alloxan-induced diabetic mice and could be potential candidate for the detailed molecular studies and management of diabetes.

Keywords: Alloxan, Diabetes mellitus, Antihyperglycemic activity, Antioxidative activity, Metformin, Phlogacanthus thyrsiflorus.

(C) 2018 The Authors. Published by Innovare Academic Sciences Pvt Ltd. This is an open access article under the CC BY license (http://creativecommons. org/licenses/by/4. 0/) DOI: http://dx.doi.org/10.22159/ajpcr.2018.v11i7.25393

\section{INTRODUCTION}

Diabetes mellitus (DM) is a serious global health problem with 415 million population are under its grip worldwide in 2015 and this might extend to 642 million by 2040 [1]. Diabetes, also termed as DM, is a metabolic disorder characterized by chronic hyperglycemia. Deficiency of insulin secretion, insulin action, or both could lead to metabolic disturbance of carbohydrate, fat, and protein [2]. The prolonged hyperglycemia during DM stimulates increased production of free radicals through several mechanisms such as polyol pathway, glucose oxidation, and advanced glycation end product formation $[3,4]$. Therefore, there are enzymic and non-enzymic antioxidant defense systems in mammalian cells that minimize the cellular damage caused by free radicals. However, the relative overload of free radicals and lowering of antioxidant defense systems activities in DM added with the generation of more oxidative stress that results in pathogenesis and complications of diabetes $[5,6]$.

The DM is considered to be a global problem and successful treatment has yet to be discovered. Although insulin therapy and oral hypoglycemic agents are available for the treatment of diabetes and are also effective in controlling hyperglycemia, they are associated with many side effects and failed to significantly alter the course of diabetic complications. Medicinal plants and their bioactive compound are used as an alternative method to treat the diabetes patient throughout the world since the $6^{\text {th }}$ century [7]. A current research on free radicals has evaluated that foods which are rich in antioxidants possess an essential role in the prevention of adverse effects caused by diabetes. Resultantly, natural antioxidants, that are ubiquitous in fruits, leaves, and flowers, have received great attention and have been studied extensively, as they are effective free radical scavengers and are presumed to be less toxic than synthetic antioxidants [8]. Literature also reports about 800 plants which may possess antidiabetic potential [9].
Phlogacanthus thyrsiflorus is an herb from a family of Acanthaceae, which has several common names such as titaaphul, chuhai, and tangkhul. $P$. thyrsiflorus is one of the common medicinal plants used by local people of Assam to manage diabetes [10]. P. thyrsiflorus produces a number of secondary metabolites such as alkaloids, flavonoids, steroids, triterpenoids, polyphenols, and glycosides. It has free radical scavenging property so it may prove as a very good medicinal herb [11]. In this regard, it makes great sense to evaluate the antidiabetic and antioxidative properties of flowers extract in alloxan-induced diabetic mice model.

\section{METHODS}

\section{Chemicals}

Alloxan, pyrogallol, and metformin were procured from Sigma-Aldrich Co. (St. Louis, MO, USA). Insulin was purchased from Gland Pharma Ltd. (Hyderabad, India). The other chemicals used were of analytical grade ordered from Merck Co. (Mumbai, India) and Sisco Research Laboratory.

\section{Plant material}

Flowers of $P$. thyrsiflorus were collected from Assam, India (Voucher No: 12055). The specimen was submitted and identified by Dr. P.B. Gurung Curator herbarium, Department of Botany, NEHU, Shillong, Meghalaya.

\section{Aqueous and methanolic extracts preparation}

The flowers were separated, weighed, washed, and dried in the shade. It was then grinded to powder form using a grinder. Aqueous flower extract (AFE) was prepared by macerating with distilled water ( $10 \mathrm{x}$ volumes) for $24 \mathrm{~h}$ at room temperature with continuous stirring. It was then filtered through Whatman paper number 1 . The filtrate was transferred into lyophilized tube and freeze dried (lyophilization) for 1-2 days and stored in $-20^{\circ} \mathrm{C}$ freezer for further use [12]. Similarly, methanolic flower extract (MFE) was prepared by extracting it with $10 \mathrm{x}$ volume of methanol:aqueous 
solution (4:1). After overnight stirring (extracting), the mixture was filtered and the filtrate evaporated to dryness at $40^{\circ} \mathrm{C}$ in a rotary evaporator [12]. The dried mass was stored and used for further investigations.

\section{Phytochemical screening}

Phytochemical screening were carried out on both AFE and MFE examining the chemical secondary metabolites of alkaloids, flavonoids, glycosides, tannins, terpenes, and saponins [13-15].

\section{Test animals}

Adult healthy male Swiss albino mice (Balb/C strain), 20-30 g in weight, were used for all the investigations. Procedure of all the experiments was reviewed and carried out in accordance with the institutional ethics committee guidelines (Animal models), 04-12-2014. Mice were housed in a polycarbonate cage under controlled temperature, i.e., at $22^{\circ} \mathrm{C}$ on a $12 \mathrm{~h}$ light/dark cycle and were fed with mice feed obtained from laboratory of Amrut, Pune, India, and water ad libitum.

\section{Induction of DM in test animals}

Alloxan monohydrate $(150 \mathrm{mg} / \mathrm{kg}$ body weight [b.w]) dissolved in citrate buffer (0.1 M, pH 4.5) was intraperitoneally administered to overnight fasted test mice for induction of diabetes [16]. After $72 \mathrm{~h}$ of alloxan injection, mice with fasting blood glucose (FBG) above $200 \mathrm{mg} / \mathrm{dl}$ were considered as diabetic and included in the investigations.

\section{Antihyperglycemic study}

Alloxan-induced diabetic mice were divided into one control and five test groups comprising five mice in each group. Control group, consisting of diabetic mice, administered with only distilled water and diabetic mice in test groups were administered with increasing doses (150 mg/kg b.w-550 mg/kg b.w) of MFE intraperitoneally to carry out the antihyperglycemic study. After injection, FBG levels were monitored at $0.5 \mathrm{~h}, 1 \mathrm{~h}, 2 \mathrm{~h}, 4 \mathrm{~h}$, and $6 \mathrm{~h}$. After $6 \mathrm{~h}$, the mice were fed and blood glucose levels were monitored at $24 \mathrm{~h}$ [17].

\section{Antioxidant enzyme assays}

Swiss albino mice were divided into four groups consisting of five mice in each group for the study. Doses were intraperitoneally administered in alternate days for a total of 21 days.

Group 1: Normal mice administered with distilled water

Group 2: Diabetic mice administered with distilled water.

Group 3: Ascorbic acid (50 mg/kg b.w) treated diabetic mice.

Group 4: MFE (250 mg/kg b.w) treated diabetic mice.

Kidney tissues were extracted after sacrificing by decapitation on $21^{\text {st }}$ days. Tissues were homogenized to make $10 \%(\mathrm{w} / \mathrm{v})$ homogenate in ice cold $10 \mathrm{mM}$ HEPES buffer, $\mathrm{pH} 7.4$ containing $0.2 \mathrm{M}$ mannitol, $50 \mathrm{mM}$ sucrose, and $1 \mathrm{mM}$ EDTA. Nuclei and cell debris were sedimented by centrifuging tissue homogenate for $10 \mathrm{~min}$ at $4^{\circ} \mathrm{C}$ at $1000 \mathrm{~g}$. The supernatant collected was again centrifuged for $10 \mathrm{~min}$ at $4^{\circ} \mathrm{C}$ at $7500 \mathrm{~g}$. Mitochondrial fraction was obtained with the resulting mitochondrial pallet from above procedure being washed gently by suspending in homogenate buffer and then resedimented at $7500 \mathrm{~g}$ for $10 \mathrm{~min}$ at $4^{\circ} \mathrm{C}$. Cytosolic fraction was obtained by centrifuging the post-mitochondrial supernatant further for $10 \mathrm{~min}$ at $4^{\circ} \mathrm{C}$ at $1500 \mathrm{~g}$.

The protein concentration of cytosolic and mitochondria fractions was determined by Bradford method [18] using bovine serum albumin as a standard.

Both Mn-superoxide dismutase (SOD) and Cu/Zn-SOD activities were estimated according to the method of Marklund and Marklund [19]. The enzyme activities were expressed in units/mg of protein where one unit defines the amount of enzyme required to give $50 \%$ inhibition. The absorbance was read spectrophotometrically against reagent black at $\lambda 470 \mathrm{~nm}$.

Catalase (CAT) activities were determined by the method of Aebi [20]. Activities of CAT were calculated using the molar extinction coefficient of $43.6 \mathrm{~cm}^{-1}$ and were expressed as nmoles of $\mathrm{H}_{2} \mathrm{O}_{2}$ decomposed $/ \mathrm{min} / \mathrm{mg}$ protein.
Glutathione reductase (GR) activities were determined by the method of Carlberg and Mannervik [21]. The GR activities were expressed as units $/ \mathrm{mg}$ protein, and the absorbance was read at $\lambda 340 \mathrm{~nm}$ following the oxidation of NADPH.

\section{Histopathological studies}

Kidney of normal, diabetic, and treated diabetic mice were excised after 21 days by sacrificing the mice by cervical dislocation and the histolopathological studies were carried out by hematoxylin-eosin (HE) staining techniques [22]. After extractions, all the tissues were first fixed in formalin for $24 \mathrm{~h}$ then were dehydrated with ethanol gradients $(70 \%-100 \%)$ before embedding in paraffin wax. The paraffin blocks were sectioned into $7 \mu \mathrm{m}$ sized using a rotary microtome. The slice sections were fixed on glass slides, deparaffinized, and stained with hematoxylin followed by eosin stains. Eventually, the sections on glass slides were covered by coverslip mounted with DPX and observed under Olympus BX51 light microscope.

\section{Statistical analysis}

Results of all the investigations were expressed as mean \pm standard error of the mean for each group consisting of five mice in every group. Data were analyzed using one-way ANOVA followed by Tukey's post hoc test.

\section{RESULTS}

\section{Phytochemical screening}

Screening results of AFE and MFE of $P$. thyrsiflorus showed different chemical constituents in Table 1. The flavonoids and tannins were found to be strongly present in MFE, and therefore, the further studies were carried out with MFE.

\section{Antihyperglycemic study}

The result of the effects of MFE on elevated FBG levels is shown in Fig. 1. There was minimal reduction (32.2\%) of FBG level at the dose of $150 \mathrm{mg} / \mathrm{kg}$ b.w at $6 \mathrm{~h}$. However, a significant reduction (31.3\%) was observed at $250 \mathrm{mg} / \mathrm{kg}$ b.w at $2 \mathrm{~h}, 44.7 \%$ at $4 \mathrm{~h}$, and $50 \%$ at $6 \mathrm{~h}$ from that of the control group. At $350 \mathrm{mg} / \mathrm{kg}$ b.w, the FBG levels were $45.5 \%$ at $2 \mathrm{~h}, 61.3 \%$ at $4 \mathrm{~h}$, and $66.7 \%$ at $6 \mathrm{~h}$ when compared with the diabetic control group in the study. The higher doses of $450 \mathrm{mg} / \mathrm{kg}$ b.w and $550 \mathrm{mg} / \mathrm{kg}$ b.w showed drastic reduction of FBG level. At $450 \mathrm{mg} / \mathrm{kg}$ b.w, the FBG levels were $62 \%$ at $2 \mathrm{~h}, 68.2 \%$ at $6 \mathrm{~h}$, and $73.3 \%$ at $6 \mathrm{~h}$, while at $550 \mathrm{mg} / \mathrm{kg}$ b.w the FBG levels were $67.4 \%$ at $2 \mathrm{~h}, 75.6 \%$ at $4 \mathrm{~h}$, and $79 \%$ at $6 \mathrm{~h}$. Hence, $250 \mathrm{mg} / \mathrm{kg}$ b.w dose of MFE was considered to be the optimum dose for the study.

\section{Kidney antioxidant enzyme assays}

SOD (CuZn-SOD and Mn-SOD), CAT, and GR activities in kidney tissues of the experimental group are shown in Table 2. The SOD, CAT, and GR activities were reduced significantly in Group 2 (diabetic mice). However, Group 3 (ascorbic acid-treated diabetic mice) and Group 4 (extract-treated diabetic mice) showed a significant increase in antioxidant activity with increased in SOD, CAT, and GR activities in comparison to diabetic control group in the study.

\section{Kidney histopathological studies}

As shown in Fig. 2, kidney of diabetic mice, the glomerulus has been shrunken which leads to widening of Bowman's capsule space, proximal convoluted tubule (PCT) with wide lumen, lined with high and deformed cuboidal cells, distal convoluted tubule (DCT)

\section{Table 1: Phytochemical screening results of AFE and MFE}

\begin{tabular}{lll}
\hline Screening & AFE & MFE \\
\hline Alkaloids & Not present & Slightly present \\
Tannins & Slightly present & Strongly present \\
Glycosides & Slightly present & Strongly present \\
Flavonoids & Slightly present & Strongly present \\
Terpenes & Slightly present & Strongly present \\
Saponins & Strongly present & Slightly present \\
\hline
\end{tabular}


Table 2: Mean activities of SOD, CAT, and GR in kidney of different experimental groups

\begin{tabular}{|c|c|c|c|c|}
\hline \multirow[t]{2}{*}{ Groups } & \multicolumn{2}{|c|}{ SOD (Units/mg protein) } & \multirow{2}{*}{$\begin{array}{l}\text { CAT (Units/mg protein) } \\
\text { CAT }\end{array}$} & \multirow{2}{*}{$\begin{array}{l}\text { GR (Units/mg protein) } \\
\text { GR }\end{array}$} \\
\hline & CuZn-SOD & Mn-SOD & & \\
\hline Group 1 & $6.334 \pm 0.57$ & $13.46 \pm 0.42$ & $2.42 \pm 0.14$ & $3.25 \pm 0.13$ \\
\hline Group 2 & $3.4 \pm 0.15$ & $8.9 \pm 0.46$ & $1.54 \pm 0.10$ & $2.30 \pm 0.15$ \\
\hline Group 3 & $5.11 \pm 0.49^{* * *}$ & $11.6 \pm 0.26^{* * *}$ & $2.29 \pm 0.11^{* * *}$ & $3.01 \pm 0.12^{* * *}$ \\
\hline Group 4 & $5.02 \pm 0.18^{* * *}$ & $12.05 \pm 0.28^{* * *}$ & $2.24 \pm 0.09 * *$ & $2.96 \pm 0.07^{* * *}$ \\
\hline
\end{tabular}

Group 1: Normal mice, Group 2: Diabetic mice, Group 3: Diabetic mice treated with ascorbic acid, Group 4: Diabetic mice treated with MFE. Values are expressed as Mean \pm SEM, $n=5 .{ }^{* *} \mathrm{p}<0.01,{ }^{* * *} \mathrm{p}<0.001$ versus diabetic control group). SOD: Superoxide dismutase, CAT: Catalase, GR: Glutathione reductase

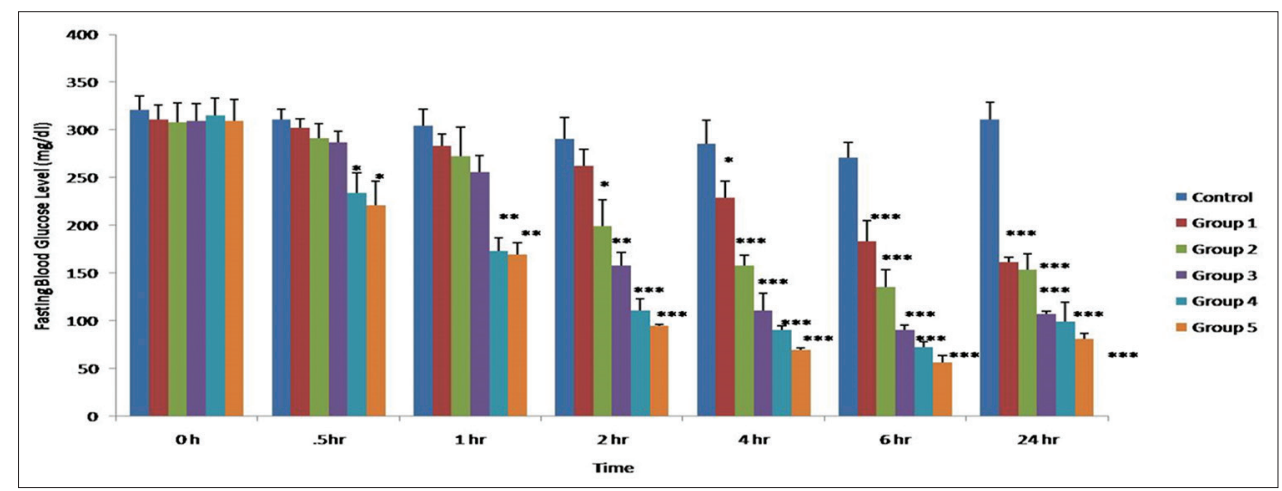

Fig. 1: Effects of methanolic flower extract on diabetic mice (short-term study) showing changes of fasting blood glucose level at different time interval for different experimental groups $(150-550 \mathrm{mg} / \mathrm{kg}$ body weight dose). Values are expressed in mean \pm standard error of the mean; $\mathbf{n}=5 .\left(* \mathrm{p}<0.05, * * \mathrm{p}<0.01,{ }^{* * *} \mathrm{p}<0.001\right)$

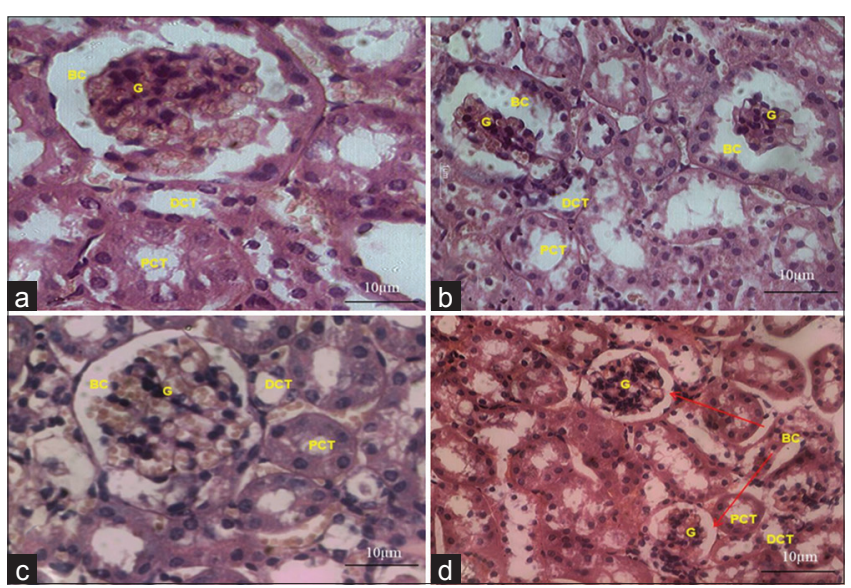

Fig. 2: Photomicrographs of section of kidney tissues showing histological changes. a: Normal mice, b: Diabetic mice, c: Diabetic mice treated with ascorbic acids, and d: Diabetic mice treated with methanolic flower extract. G: Glomerulus, BC: Bowman's capsule, PCT: Proximal convoluted tubule, DCT: Distal convoluted tubule. All images are under $\times 40$ magnifications

with wide lumen and deformed cuboidal cells when compared with normal mice. The normal physiological structure of glomerulus without much widening of Bowman's capsule space and near normal PCT and DCT was seen in both ascorbic acid- and MFE-treated diabetic mice.

\section{DISCUSSION}

Alloxan,referred toas alloxan monohydrate (2,4,5,6-tetraoxypyrimidine; 5, 6-dioxyuracil), is a known diabetogenic agent and used to induce diabetes in laboratory rats and mice. It is a toxic glucose analog that destroys pancreatic beta-cells (insulin-producing cells) [23]. Therefore, alloxan administration in mice shows a significant increase in blood glucose level in the study.
Although the AFE had a good effect on diabetes, the effect of MFE was quite better than the former. The MFE reflected the good effects due to the presence of flavonoids and tannins compound which showed in phytochemical screening of MFE, while the other extract did not have much flavonoids and tannins. Flavonoids are highly effective free radical scavengers that could scavenge oxidized molecules, including singlet oxygen, and various other free radicals implicated in several diseases [24]. Flavonoids suppress the formation of reactive oxygen, chelate trace elements involved in free radical production, scavenge reactive species, and upregulate and protect antioxidant defenses [25]. Flavonoids might have the potential of secreting insulin from existing pancreatic $\beta$-cell [26]. There might be another possibility of flavonoids that is to protect the DNA from the oxidative damage, and hence, it could resist the changes in $\beta$-cell [27]. Similarly, tannins confer oxidative stress tolerance on plants. The short-term antihyperglycemic study has revealed that $250 \mathrm{mg} / \mathrm{kg}$ b.w of MFE was able to reduce FBG level in more significant way. Hence, $250 \mathrm{mg} / \mathrm{kg}$ b.w dose of extract was considered to be an optimum dose for the study.

SOD (Mn-SOD and CuZn-SOD) presents in mitochondria and cytosol is an antioxidant enzyme that defends against reactive oxygen species. They eliminate superoxide anion to hydrogen peroxide [28]. CAT enzyme, which is also an antioxidant enzyme, neutralized hydrogen peroxide to water and oxygen [29]. GR antioxidant enzyme in cytoplasm functions through converting oxidized glutathione to reduce form GSH and helps in maintaining a balanced intracellular environment. In this study, it was found that treatment with extract restores and increases the activities of antioxidants enzymes when compared with untreated diabetic mice. Therefore, it could be said that MFE of $P$. thyrsiflorus protects the kidney tissue from further oxidative stress under diabetic condition.

From histological study, it is confirmed that MFE of $P$. thyrsiflorus has the ability to protect and restore oxidative stress injury induced by diabetes. It is also confirmed from the study that extract is able to suppress oxidative stress in the tissue and enhancing the activity antioxidative enzyme, thus allowing tissue to recover and halt from further damage. 


\section{CONCLUSION}

The findings of the present study signified that MFE of $P$. thyrsiflorus has antihyperglycemic potential and treatment with extract may provide beneficial effects against oxidative stress. However, the exact mechanism is yet to be elucidated and further investigation is underway.

\section{ACKNOWLEDGMENT}

The authors would like to thank the Department of Science and Technology (DST), New Delhi, India, for providing INSPIRE fellowship, DRS programme, for providing infrastructural support to the Department of Biochemistry, NEHU, Shillong.

\section{CONFLICTS OF INTEREST}

There are no conflicts of interest. All authors contributed immensely for this work and prepared the manuscript.

\section{REFERENCES}

1. WHO. Definition and Diagnosis of Diabetes Mellitus and Intermediate Hyperglycemia. Geneva: WHO; 2006. p. 1-50.

2. Zhang Y, Wu L, Ma Z, Cheng J, Liu J. Anti-diabetic, anti-oxidant and anti-hyperlipidemic activities of flavonoids from corn silk on STZinduced diabetic mice. Molecules 2015;21:1-11.

3. Inoguchi T, Sonta T, Tsubouchi H, Etoh T, Kakimoto M, Sonoda N, et al. Protien kinase C-dependent increase in ROS production in vascular tissues of diabetes: Role of vascular NAD(P)H oxidase. J Am Soc Nephrol 2003;14 8 Suppl 3:227-32.

4. Williamson JR, Chang K, Frangos M, Hasan KS, Ido Y, Kawamura T, et al. Hyperglycemic pseudo hypoxia and diabetic complications. Diabetes 1993;42:801-13.

5. Baynes JW, Thorpe SR. Role of oxidative stress in diabetic complications: A new perspective on an old paradigm. Diabetes 1999;48:1-9.

6. Ceriello A. Oxidative stress and glycemic regulation. Metabolism 2000;49:27-9.

7. Kashikar VS, Tejaswita K. Indigenous remedies for diabetes mellitus. Int J Pharm Pharm Sci 2011;3:22-9.

8. Dakshayini PN, Basha PM. Phytochemical screening and in vitro antioxidant potential of Tribulus terrestris fruit and Mesua ferrea flower extracts: A comparative study. Int J Pharm Pharm Sci 2018;10:70-5.

9. Alarcon-Aguilara FJ, Roman-Ramos R, Perer-Gutierrez S, AguilarContreras A, Contreras-Weber CC, Flores-Saenz JL. Study of the antihyperglycemic effect of plants used as antidiabetics. J Ethnopharmacol 1998;61:101-10

10. Jaiswal V. Culture and ethnobotany of Jaintia tribal community of Meghalaya, Northeast India-a mini review. Indian J Trad Knowl 2010;9:38-44.

11. Kshirsagar R, Upadhyay S. Free radical scavenging activity screening of medicinal plants from Tripura, Northeast India. Natl Prod Radiance
2009;8:117-22.

12. Harborne JB. Phytochemical Methods. $3^{\text {rd }}$ ed. London (NY): Chapman \& Hall Publishers; 1998.

13. Rumanti RM, Nainggolan M, Harahap U. Phytochemical screening and antidiabetic activity of different leaf extracts from lotus (Nelumbo nucifera gaertn.) in streptozotocin induced mice. Asian J Pharm Clin Res 2017;10:190-92.

14. Farnsworth NR. Biologycal and phytochemical screening of plants. J Pharm Sci 1996;55:225-76.

15. Harbone JB. Metode Fitokimia. Vol. 2. Bandung: ITB; 1987. p. 49.

16. Syiem D, Gareth S, Khup PZ, Khongwir BS, Kharbuli B, Kayang H. Hypoglycemic effect of Potentilla fulgens L. in normal and alloxaninduced diabetic mice. J Ethanopharmacol 2002;83:55-61.

17. Patar AK, Bhan S, Syiem D. Effect of chlorophyllin, an semisynthetic chlorophyll molecule on hyperglycemia and hyperlipidemia in streptozotocin induced diabetic mice. Int J Pharm Pharm Sci 2016:8:293-6.

18. Bradford MM. A rapid and sensitive method for the quantitation of microgram quantities of protein utilizing the principle of protein-dye binding. Anal Biochem 1976;72:248-54.

19. Marklund S, Marklund G. Involvement of the superoxide anion radical in the autoxidation of pyrogallol and a convenient assay for superoxide dismutase. Eur J Biochem 1974;47:469-74.

20. Aebi H. CAT in vitro. In: Packer L, editor. Methods Enzymol. Vol. 105. New York: Academic Press; 1984. p. 121-6.

21. Carlberg I, Mannervik B. Gutathione reductase assay. In: Packer L, editor. Methods Enzymol. Orlando (FL): Academic Press; 1985. p. 484-90.

22. Syiem D, Khup PZ. Evaluation of Flemingia macrophylla L.: A traditionally used plant of the north eastern region of India for hypoglycemic and anti-hyperglycemic effect on mice. Pharmacol Online 2007;2:355-66.

23. Szkudelski T. The mechanism of alloxan and streptozotocin action in B Cells of the rat pancreas. Physiol Res 2001;50:537-46.

24. Bravo L. Polyphenols: Chemistry, dietary sources, metabolism and nutritional significance. Nutr Rev 1998;56:317-33.

25. Agati G, Azzarello E, Pollastri S, Tattini M. Flavonoids as antioxidants in plants: Location and functional significance. Plant Sci 2012;196:67-76

26. Kar MK, Swain TR, Mishra SK. Antidiabetic activity of Clerodendrum serratum L. moon leaves in streptozotocin-induced diabetic rats. Asian J Pharm Clin Res 2014;7:260-3.

27. Mujic A, Grdovic N, Mujic I, Mihailovic M, Zivkovic J, Poznanovic G, et al. Anti-oxidative effects of phenolic extracts from chestnut leaves, catkins and spiny burs in streptozotocin-treated rat pancreatic $\beta$-cells. Food Chem 2011;125:841-9.

28. Evans JL, Goldfine ID, Maddux BA, Grodsky GM. Are oxidative stress-activated signalling pathways mediators of insulin resistance and \{beta\}-cell dysfunction? Diabetes 2003;52:1-8.

29. Johansen JS, Harris AK, Rychly DJ, Ergula A. Oxidative stress and the use of antioxidants in diabetes: Linking basic science to clinical practice. Cardiovasc Diabetol 2005;4:5. 